UNIO - EU Law Journal. Vol. 3, No. 2, July 2017, pp 125-138.

®2017 Centre of Studies in European Union Law

School of Law - University of Minho

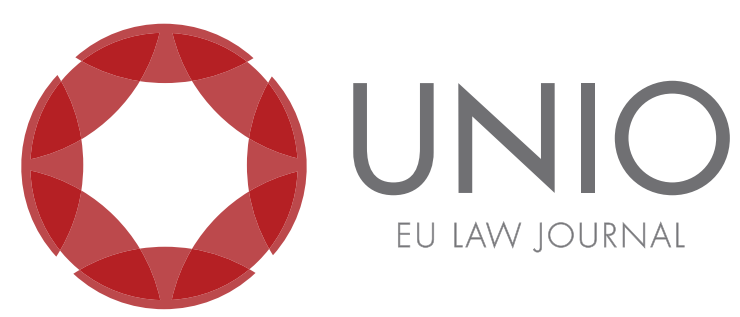

\title{
The multilingual jurisprudence of the Court of Justice and the idea of uniformity in European Union Law
}

\author{
Joana Sousa Domingues*
}

ABSTRACT: It is generally accepted that the development of a Union of law is largely due to the judicial decisions of the Court of Justice of the European Union (hereinafter, CJEU). With its judicial pronouncements, the CEJEU aims to achieve the same legal effects in every language version of its judgments and, through them, to ensure the uniform application and interpretation of European Union law. Nevertheless, such judicial pronouncements, with normative and binding force, are the result of collegial decisions and drafted by jurists in a language that is usually not their mother tongue. In addition, they are also the result of various permutations associated with the necessary legal translation from and to (and vice versa) the working language of the Court and the official languages of the European Union. The published judgments presented as authentic are, in most cases, translations. To understand the construction of decisions of the CJEU is to understand the construction of the European Union law, and by consequence, the European project itself.

KEYWORDS: Court of Justice of the European Union - law and language - lanyer-linguists - référendaires - uniformity.

\footnotetext{
* Master's student in European Union law at the University of Minho.
} 


\section{European Union law}

The legal scholarship has long recognized the importance of the CJEU as an engine of European integration. An integration that is, first, and foremost legal, and promoted through the practice of interpretation and the influence of the judicial institution of the European Union.

If in the past, the CJEU could be described as 'tucked away in the fairyland Grand Duchy of Luxembourg, and blessed with benign neglect by the powers that be and the mass media, ${ }^{1}$ in the last sixty years of European integration, the role of the CJEU in making explicit the legal meaning of the rules of European Union law (hereinafter, EU law) has attracted increasing attention. As well as the role of the national courts which, in the final analysis, are responsible for applying the judicial decisions of the CJEU in accordance with the correct interpretation ascribed to EU law by the Court with effect on disputes pending at the national level. In this sense, the importance of the case-law of the CJEU goes far beyond the dispute in respect of which interpretative questions are specifically addressed. This is so, despite the absence of any official doctrine of precedent in EU law.

It is often overlooked that the objects of interpretation of the CJEU are multilingual legal rules of EU law. The EU legislation takes form in a complex procedure that combines drafting and translation. The "final product" is a multilingual legislative instrument. In order to respect the principle of equal authenticity, all language versions are regarded as authentic and create a single legal instrument. As in other multilingual legal systems, the task of establishing the meaning of EU law is delegated to the courts.

The CJEU's decisions on the correct interpretation of the EU law are also nuanced by the language and translation. Those decisions are expressed in judgments drafted in French by both native speakers and non native speakers. The process that leads to the final judgment is equally complex and dynamic, characterised by a particular merger between drafting and translation, in a multilingual and multicultural setting. More specifically, the judgments are based on translated and retranslated documents. Given that only the texts of documents drawn up in the language of the case shall be authentic, the final "authentic" judgment, this is, binding, is most of the times, a translation.

With its decisions, the CJEU intends to produce statements of law which achieve the same legal effects in every published language version and thus, ensure the uniform application and interpretation of EU law, ${ }^{2}$ committing itself to the development of a body of jurisprudence that has revealed itself as a key factor in the process of European integration.

How do these linguistic aspects of the judicial decision-making in the CJEU affect the notion of uniformity in EU law? Or, more specifically, taking into account the factors which inform the case-law of the CJEU, can we really speak of uniform law in a Union with 28 Member States? To answer these questions, the present analysis aims, by adopting a systemic lens, to look at how the multilingual jurisprudence of the CJEU is produced and the impact of language in that jurisprudence and the limitations of this jurisprudence, in light of the intention of uniformity that it seeks

\footnotetext{
${ }^{1}$ Eric Stein, "Lawyers, Judges and the Making of A Transnational Constitution", in American Journal of International Law, 1, vol. 75 (1981), 1.

${ }^{2}$ See Article 19(1), first paragraph of the Treaty on European Union.
} 
to achieve. We chose to focus the present study on the CJEU ${ }^{3}$ and, in particular, in the Preliminary Reference Procedure. ${ }^{4}$

\section{Language arrangements of the CJEU}

We shall begin by examining the rules governing the use of languages before the CJEU.

According to Article 7 of Council Regulation (EEC) No. 1/58 determining the languages to be used by the European Union (hereinafter Council Regulation No. 1), ${ }^{5}$ although the CJEU is subject to the general rules for language set forth in this Regulation, it can develop autonomous provisions concerning language arrangements for proceedings before the Court. Those provisions are set out at Chapter 8 (Articles 36 to 42) of the Rules of Procedure of the Court of Justice. ${ }^{6}$

Firstly, it is necessary to distinguish between the language of the case and the working language of the CJEU.

\section{The language of the case}

Article 36 of the Rules of Procedure of the Court determines that all of the 24 official languages of the European Union can be the language of a case. ${ }^{7}$

Each action has its own rule to determine the language of a case. ${ }^{8}$ In the Preliminary ruling proceedings, the language of the case is always that used by the national court or tribunal which made the reference. ${ }^{9}$ Once determined, the language of the case must be used, in principle, throughout the proceedings both in the written and in the oral procedure. ${ }^{10}$ Which means that it will be the language used in any written or oral observation of the parties, any procedural document and its annexes, as well as in the oral arguments and written documents in the process. All documents (correspondence, reports or decisions, etc. ${ }^{11}$ are exchanged between the Registry and

\footnotetext{
${ }^{3}$ The Court of Justice of the European Union consists, currently, of two courts: the Court of Justice and the General Court.

${ }^{4}$ According to the Annual Report on the Judicial Activity 2016 of the Court of Justice of the European Union, there is been an increase in on references for a preliminary ruling. In the past four years $2 / 3$ of the cases decided by the Court of Justice were references for a preliminary ruling. Court of Justice of the European Union, Annual Report on the Judicial Activity 2016 [available at www.curia. europa.eu, last accessed June 1, 2017], see in particular p.91. The importance of the preliminary ruling procedure is fuss visible.

${ }^{5}$ Council Regulation (EEC) No 1/58 determining the languages to be used by the European Economic Community, OJ P 017, 06.10.1958, pp. 385-386, with the last amended by Council Regulation (EU) No 1257/2010 of 20 December 2010. Regulation no. 1, April 15, 1958, determining the languages to be used by the European Atomic Energy Community, OJ P 017 06.10.1958, pp. 401-402.

${ }^{6}$ Court of Justice of the European Union, Rules of Procedure of the Court of Justice, OJ L 265, 29.9.2012, p. 1-42.

${ }^{7}$ Currently, the official languages of the EU are (in English alphabetical order): Bulgarian, Czech, Danish, Dutch, English, Estonian, Finnish, French, German, Greek, Hungarian, Italian, Irish, Latvian, Lithuanian, Maltese, Polish, Portuguese, Romanian, Slovakian, Slovenian, Spanish and Swedish (Article 1 of Council Regulation No 1).

${ }^{8}$ See, Article 37 of the Rules of Procedure of the Court of Justice.

${ }^{9}$ See, Article 37 (3) of the Rules of Procedure of the Court of Justice.

${ }^{10}$ See, Article 38 (1) of the Rules of Procedure of the Court of Justice. This rule is subject to various exceptions provided in Article 38 (4-6) and Article 37(3) of the Rules of Procedure of the Court.

${ }^{11}$ See, Article 38 (1 and 2) of the Rules of Procedure of the Court of Justice.
} 
the parties in the language of the case. ${ }^{12}$

The CJEU publishes its judgments in all the official languages (with the exception of Irish). ${ }^{13}$ Only the texts drawn up in the language of the case are authentic. ${ }^{14}$

\section{The working language}

Despite being presented as a multilingual institution, ${ }^{15}$ in favour of pragmatism, the CJEU operates using a single working language. Unlike in other European institutions, working mostly in English and French, the CJEU, just as the village of Asterix that still resists, has maintained a single working language - French. ${ }^{16}$ This means that this is the language used in the internal workings at the Court, as for example, in the deliberations and the drafting of preliminary reports, judgments and orders. According to Article 38 (8) of the Rules of Procedure of the Court, Judges and advocates general may request for translation, in a language of their choice, of any document. However, the members of the Court rarely use this prerogative, so as not to increase the workload of the translation service.

From the previous analysis of the rules governing language use at the CJEU we can infer that the Court took into account one of the most important functions of any judicial institution - its communication. The CJEU communicates in two ways: it communicates internally, ensuring linguistic uniformity, using French as the language of deliberation and drafting; and, externally, respecting the principle of multilingualism, with 24 official languages ensuring "that its case-law is disseminated throughout the Member States". ${ }^{17}$ It follows that translation is of utmost importance.

\section{Court of Justice: multilingual and multicultural aspects}

The jurisprudence of the CJEU is the result of intellectual and therefore, human work. In particular, the CJEU is intrinsically interesting for its internal diversity. The final product of the work of the CJEU is the result of a continuous process of a mixture of various legal systems, cultures, traditions, and languages. As such, its caselaw is shaped to the dynamics of this institution.

As evidenced by the judge Sacha Prechal in the late 1980s and early 1990s, the institution has evolved from "a bit of a family" to "a bit of a factory". ${ }^{18}$ In its early years, the Court of the six original Member States was reasonably homogeneous. Today,

\footnotetext{
${ }^{12}$ See, also, Article 39 (1) of the Rules of Procedure of the Court of Justice.

${ }^{13}$ See, Article 40 of the Rules of Procedure of the Court of Justice.

${ }^{14}$ See, Article 41 (2) of the Rules of Procedure of the Court. In theory the Court produces jurisprudence in all official languages. In practice, however, not only it does not do so in the Irish language, as not all judgments are translated to be published.

${ }^{15}$ In fact, in the "General Presentation" of the Court of Justice of the European Union, as set out in its own Website, it can be read in the second paragraph: "As each Member State has its own language and specific legal system, the Court of Justice of the European Union is a multilingual institution".

${ }^{16}$ This is an institutional practice is established, based on tradition and not in a legal provision imposing its use. In fact, is the Court itself that says so in its own Website: "The Court needs a common language in which to conduct deliberations. That language is, by custom, French".

${ }^{17}$ Ibidem, footnote 15.

${ }^{18}$ Interview with the judge Sacha Prechal the Court of Justice: "Part I: Working at the CJEU" of 18 December 2013, [available at http://europeanlawblog.eu, last accessed June 1, 2017]. Even so, the Court can be considered as a relatively small institution. According to the data on the judicial year of 2015, just over 2000 people currently work at the Court of Justice. Court of Justice of the European Union, Management Report 2015, [available in www.curia.europa.eu last accessed June 1, 2017], pp. 47 and 95 and subsequent.
} 
with 28 Judges and 11 Advocate Generals, the members of the Court come from 28 different legal traditions and cultures, covering a large number of legal families. In addition, in performing its duties, the members of the Court have at their disposal, a variety of departments, such as the translation service. In addition, Judges and Advocate Generals are assisted by three or four référendaires. All of them also bring to the Court a diverse cultural, linguistic and legal background.

In this respect, former judge of the CJEU Giuseppe Mancini and his co-author David Keeling, give us a "privileged view" of the decision-making process in the Court. They reveal how cultural, linguistic and other factors affect the way Judges think about their roles, interact with each other and, eventually, reach decisions. ${ }^{19}$

To accommodate all these differences, the CJEU has adjusted its working methods. For example, the importance of the written procedure is, inter alia, a reflection of the needs of the Court, as a body that operates in a linguistically complex jurisdiction, since it can be argued that it is easier to understand a legal argument if we have the opportunity to study it in a written document, rather than orally at a hearing, often through simultaneous interpretation.

As stated by the former judge of the CJEU, Sir Konrad Schieman, such diversity entails, problems of perception: "[w] hat is a self-evident truth to a French lanyer is frequently not a self-evident truth to an English lanyer, and vice versa?". ${ }^{20}$ This is a problem that could be averted by communicating in a single working language.

In this regard, Giuseppe Mancini denotes that the French speakers have an advantage: "[y]et the fact of having to speak French, which has been the Court's working language since 1952, in the deliberation room and having to draft judgments in French, puts the non-francophones at a definite disadvantage vis-à-vis their brethren from France, Belgium and Luxembourg. Being of course accomplished gentlemen, they would never consciously take advantage of their colleagues' handicap; but the full mastery of a language — is an irresistible weapon; and the owner of that weapon will not be likely to refrain from using it." 21

Despite this plurality, the vast majority of the référendaires and about $30 \%$ of the staff at the CJEU in general, are French nationals or came from French-speaking countries. ${ }^{22}$ As will be argued below, référendaires play a crucial role in the development of the jurisprudence of the Court. The task of drafting all the internal written documents of the CJEU is the job of the référendaires. Hence, the internal linguistic option of the CJEU may possibly influence the substantive law produced.

\section{The multilingual jurisprudence of the CJEU}

\section{i. External linguistic factors}

When choosing a legal meaning from a range of possible meanings, the CJEU

\footnotetext{
${ }^{19}$ See, Giuseppe Federico Mancini and David T. Keeling, "Language, culture and politics in the life of the European Court of Justice", in The Columbia Journal of European Law 3, vol. 1 (1995), 397-413.

${ }^{20}$ Sir Konrad Schieman, "The application of general principles of Community law by English courts", in European Community Law in the English Courts, ed. Mads Tønnesson Andenaes and Francis Geoffrey Jacobs (Oxford: Clarendon, 1998), 139.

${ }^{21}$ Giuseppe Federico Mancini and David T. Keeling, "Language, culture and politics in the life of the European Court of Justice", 398.

22 According to data collected and provided by the Court of Justice, in March 2015, the author Angela Zhang concluded that $42 \%$ of référendaires at the Court of Justice are citizens of Belgium, France and Luxembourg. See, Angela Huyne Zhang, "The Faceless Court", in King's College London Law School Research Paper 45, (2015), 43.
} 
has, as its starting point, and limits to its judicial activity, the text of the law, the circumstances of the particular case and the parties' observations and submissions.

\section{Multilingual Legislation}

The EU legal rules take form in a complex process of "come and go" between drafting and translation.

From the perspective of judicial interpretation, the multilingual character of EU legislation is particularly important, given that all language versions are considered, in compliance with the principle of equal authenticity, ${ }^{23}$ automatically equivalent and have equal legal value and meaning in judicial interpretation. In this sense, the judgments of the CJEU, on the correct interpretation of EU legislation, are based on these original translated legal instruments. It is presumed that all language versions convey the same meaning. However, equivalence - understood as identity - is nothing more than an illusion. In the best cases, legal translation - as, indeed, any type of translation - is only an approximation. It is, in fact, commonly accepted by the theory of translation that the concept of full equivalence does not exist.

Moreover, the language used by the European Union legislator often lacks transparency and clarity, which stems from the way in which the legislative text was created. The ambiguity of the text generates problems of interpretation. The Court will then, have to find a clear legal meaning, steaming from ambiguous texts and without an official source text.

\section{Reference for a preliminary ruling}

The Preliminary ruling Procedure and its written procedure, is initiated with the decision of the national court to suspend the national dispute and submit a request for a preliminary ruling.

In relation to the form of the text produced by national courts, it should be noted that there is no formal rule on how it should be written, since each national law system has its own procedural issues. There is, however, a guide called "Recommendations to national courts and tribunals, in relation to the initiation of preliminary ruling proceedings", ${ }^{24}$ which has non-binding guidelines that nonetheless must be carefully followed. Problems arise when those guidelines are not observed, especially the guidance presented in paragraph 14, "owing to the consequential need to translate it into all the official languages of the European Union, the request for a preliminary ruling should therefore be drafted simply, clearly and precisely by the referring court or tribunal, avoiding superfluous detail'.

The request for a preliminary ruling will not necessarily be read in its original version, but in its translated version. The national court must, therefore, strive to ensure that the message is transmitted as effectively as possible after translation. If the writing meets those golden rules, the request will be translated more quickly, better and, above all, will ensure that it is properly understood. ${ }^{25}$ The purpose of the

\footnotetext{
${ }^{23}$ According to this principle, all language versions are taken as authentic, that is with equal legal value, and any distinction between original text and final (translated) version does not exist to respect this authenticity.

${ }^{24}$ Court of Justice of the European Union, Recommendations to the attention of national courts concerning the submission of preliminary ruling proceedings, OJ C 439/1, 25. 11. 2016, p. 1.

25 There is currently a rule at Court of Justice according to which requests for preliminary rulings that exceed 20 pages will be summarized. In these cases, Article 98 of the Rules of Procedure of the Court, the parties and others will be informed that it corresponds to a translated version of the
} 
request for a preliminary ruling is to assist the national judge in resolving the dispute in the main proceedings by solving a problem of interpretation. The Court will be better prepared to provide meaningful guidance if it understands what the problem is. It is for the national court to clearly inform the CJEU about the legal and factual context of the dispute in the main proceedings, concerning the interpretation of EU law it seeks clarification on. If the text is not reasonably clear, it is correspondingly more difficult to produce intelligible judgments.

\section{Written Observations of the parties, the States and the institutions}

Although the Written Observations are also not subject to any particular formalism, there is a document called "Practice directions to parties concerning cases brought before the Courl' 26 which contains provisions on how to present them. The Written Observations are drafted in different languages and translated into the language of the case and the working language of the Court and "constitute the basis for the Court's study of the file" ${ }^{27}$ When preparing the preliminary report, the judge-rapporteur will base its work on what was submitted by the parties to the main proceedings and other interested parties. It follows that the Written Observations should be able to summarise and facilitate their presentation to the members of the CJEU.

Simplicity, clarity and brevity are the rules to be observed when drafting these Observations so they can also be easily translated and understood, thereby ensuring the Court can use them to do its job effectively.

\section{ii. The production of the multilingual jurisprudence of the CJEU}

\section{i. The Drafting Stage}

\section{Référendaires $^{28}$}

Dubbed as "bommes et femmes de l'ombre" and "ghost writers", 29 the référendaires play a vital role in the development of EU law. Angela Zhang designates them as the "bidden workforce within the Court". ${ }^{30}$ With legal and linguistic knowledge, ${ }^{31}$ they ease the workload of the members of the CJEU and participate in oral and written interactions between the cabinets and the translation service.

Each Judge and Advocate General of the Court has a cabinet, composed by three or four référendaires, who work exclusively for that Judge/Advocate General. The minimum requirement to be a référendaire at the CJEU is to be a qualified lawyer

summary of that request. Eventually, the request can also be reformulated by the judge-rapporteur and its référendaires.

${ }^{26}$ See Court of Justice of the European Union, Practice directions to parties concerning cases brought before the Court, OJ L 031, 31.01.2014, p.1.

${ }^{27}$ See Court of Justice of the European Union, Practice directions to parties concerning cases brought before the Court, paragraph 37.

${ }^{28}$ The référendaires are personal legal assistants, but are commonly referred to by its French denomination.

${ }^{29}$ Michal Bobeck, "The Court of Justice of the European Union", in College of Europe Research Paper in Law 2, (2014), 13.

${ }^{30}$ See, Angela Huyne Zhang, "The Faceless Court”,14.

${ }^{31}$ It should be noted, moreover, that référendaires have different backgounds and do not necessarily have to have the same nationality of the judge/advocate general with whom they work with. 
and to have reasonable knowledge of EU law and French. ${ }^{32}$

Even though a "perfect" command of the French language is not required, if the reférendaire is not sufficiently capable of communicating in French, this may hinder the work he/she develops.

The role of the reférendaires is to assist the Judge/Advocate General in the writing of the first drafts of all documents coming out of the cabinets of the members of the CJEU. To do so, they carry out the necessary legal research, analyse the relevant legislation and jurisprudence.

In the Preliminary ruling Procedure, when the Written Observations have been submitted and, finally, translated into the working language of the Court and the language of the case, they are sent to the Judge-rapporteur and, eventually, to the Advocate General. ${ }^{33}$ At this stage of the process, it is up to the reférendaires to draft the preliminary report, and, in parallel, the Opinion of the Advocate General, in collaboration with their Judge-rapporteur and/or Advocate General, respectively. Once the Opinion of the Advocate General is presented ${ }^{34}$ (usually three weeks after the oral hearing) it will be sent to the Judge-rapporteur. Having considered the Opinion, the Judge-rapporteur and his/her référendaires draft, in French, the draft judgment, and, after the deliberation, the final judgment.

All of these documents are drafted by the reférendaires, with the exception of the Opinions of the Advocate Generals, ${ }^{35}$ in French, although, for most of those, that language is not their mother tongue. As noted by a référendaire interviewed by the author Karen McAuliffe, "I tend to translate what I want to say into French instead of really working in French". ${ }^{36}$ Some of those référendaires consider as a positive aspect, having to write in a language that is not their mother tongue. As the judgments have to be drafted in its own rigid style, 'working in 'Court French' is actually easier than drafting in your own language (...)".37

The drafting style varies according to the type of document in question. Judges and réferendaires are constrained by the collegial nature and the rigid style of the judgments. They should also observe the style and language of previous judgments. In contrast, the drafting of the Opinions of the Advocate Generals is significantly more liberal resembling an academic document where one can read reviews on the decisions of national courts, references to Member States' national legislation and academic publications. Since they are drafted more clearly and, by consequence, are

\footnotetext{
${ }^{32}$ See Martin Johansson, "The role and importance of legal secretaries", in Competition Law Insight 7 , vol. 6 (2007), 11.

${ }^{33}$ According to the Article 20 of the Statute of the Court of Justice of The European Union: "Where it considers that the case raises no new point of law, the Court may decide, after hearing the Advocate General, that the case shall be determined without a submission from the Advocate General". See Protocol number 3 on the Statute of the Court of Justice of the European Union, annexed to the Treaties, last amended by Regulation (EU) No 2015/2422 of the European Parliament and of the Council of 16 December 2015, OJ L 341, 24.12.2015, pp. 14-17.

${ }^{34}$ When appropriate, as referenced in the precedent footnote

35 The opinion of the advocates general are drafted in their mother tongue or in one of the pivot languages of Court of Justice: English, French, German, Spanish and Italian.

${ }^{36}$ See Karen McAuliffe, "The Limitations of the Multilingual Legal System", in International Journal for the Semiotics of Law 4, vol. 26, (2013), 869.

${ }^{37}$ See Karen McAuliffe, "Language and Law in the European Union: The Multilingual jurisprudence of the ECJ", in The Oxford Handbook of Language and Law, eds. Lawrence M. Solan and Peter M. Tiersma (Oxford: Oxford University Press, 2012), 206.
} 
more understandable, ${ }^{38}$ the Opinions of the Advocate Generals serve an important communicative function: they ease the discourse among the legal community (academics, national courts, lawyers in general) and the CJEU, and vice-versa, bridging the gaps that the judgments may have in this domain, helping in the understanding of the decision of the Court.

\section{ii. The Translation Stage}

David Edward, a former judge of the Court of Justice, described the significant burden of translation at the Court as follows: "[i]t is like a buge hourglass into which is poured, thousands of documents in different languages. In the middle everything is processed in French so that the cases can be judged and the judgment written. Then there is another buge outpouring into the bottom of the hourglass so that the judgments can be translated into the other languages and published to the outside world." 39

It is, therefore, not surprising that the biggest department of the Court is the translation service, with 23 language units, 613 lawyer-linguists, 24 potential languages of the case, 552 possible language combinations and over a million pages of translation produced annually. ${ }^{40}$

\section{Lawyer-linguists}

Given the importance of the very nature of the judicial work of the CJEU, which aims to gradually develop an EU law that can be interpreted relatively uniformly throughout the European Union, although expressed in more than 20 different languages, by virtue of the highly technical nature of the legal texts to be translated in order to carry out this task of translation, the Court employs only lawyer-linguists who have a dual professional identity.

According to Article 42 of the Rules of Procedure of the Court of Justice "[t]he Court shall set up a translating service staffed by experts with adequate legal training and a thorough knowledge of several official languages of the Court'. ${ }^{41}$

In the Preliminary ruling Procedure, lawyer-linguists are responsible for the translation of all the written documents drafted externally - requests for a preliminary ruling, Written Observations, applications to intervene by third parties - and the documents drafted internally - notice of the questions referred for a preliminary ruling in the Official Journal of the EU, reports from the Judge-rapporteur, the Opinion of the Advocate General, the judgment and the press release with the summary of the judgment. The subsequent work of the Judges and Advocate Generals will rely on these translations. As the Advocate General Eleanor Sharpston clarifies, "everything I

\footnotetext{
${ }^{38}$ Indeed, as being the product of a single mind, unlike the judgments in which the decision-making depends on the consensus, and drafted in a language that, if not the advocate general's mother tongue, it will be at least one language of their choice, definitely makes the Opinion more accessible. In addition to that, as noted by the author Karen McAuliffe the référendaires usually have the same mother language of as the advocate general for which they work with. See, Karen McAuliffe, "Language and Law in the European Union: The Multilingual jurisprudence of the ECJ" (New York, 2012), 208.

${ }^{39}$ David Edward, quoted by Hugo Brady, Twelve things everyone should know about the European Court of Justice, a report published by the Center for European Reform, July 2014, [available at: www.cer.org. uk last accessed June 1, 2017].

${ }^{40}$ Court of Justice of the European Union, Annual Report on the Judicial Activity 2016 [available at www.curia.europa.eu, last accessed June 1, 2017], p.42.

${ }^{41}$ Currently there is no longer required that French is one of these languages.
} 
read, I look at through the eyes of my lawyer-linguists". ${ }^{42}$

The need for translation presents several problems. Firstly, it limits the length of the documents to be drafted as otherwise the time expended on translation would be exponentially greater. ${ }^{43}$ Furthermore, lawyer-linguists deal with all the classic translation problems such as ambiguity, translation of "untranslatable" legal concepts, etc. As linguists, they must accept the inherent approximation of translation. The decision of the CJEU, once drafted, with all the weaknesses it might have, particularly because of the secrecy of deliberations and the collegiate nature of the decisions, has yet to be translated. The lawyer-linguist will have to maintain the statement of law the Court wished to make, transposing it to another language with its own specialties, in particular, with legal concepts inherent in the national legal system concerned, keeping those that are characteristic of the legal language of the "Court French". ${ }^{44}$

The process of translated production of the jurisprudence of the CJEU is quite complex, but it is necessary for the workings and communication, both internally and externally, of this jurisdiction and to the application of the principle of multilingualism.

\section{The influence of the language in the final result}

Having introduced the institutional dynamics and the linguistic aspects of the textual production process of the decisions of the CJEU, we will now focus on the final result - the judgment.

\section{i. Terminological consistency}

All the judgments of the CJEU are, for all the foregoing, uniquely drafted in French, which, arguably, makes the standardisation of terminology relatively easy, both in the original text, as adopted by the Judges, as in any of the 23 languages of translation, since there is only one original version (the French one), all others are translations.

In fact, the CJEU seems quite concerned with linguistic uniformity - necessary for gradually building a consistent/coherent body of case-law and a Union based on the rule of law - and, to this end, it also counts on the important technical role carried out by those known as lecteurs d'arrêt, who are responsible for the linguistic scrutiny of the judgments in its French version.

French-speaking natives, the lecteurs d'arrêt, are responsible for examining the French versions in order to ensure consistency of style and terminology, the correction

\footnotetext{
${ }^{42}$ Eleanor Sharpston, "Language Law and the (Golden) Towers of Babel" (paper presented at the Members' Day of The Chartered Institute of Linguists (CIOL), London, October 1, 2014). In the same paper the author draws a comparison between the work of lawyer-linguists at Court of Justice and the blood stream of the human body: as the latter does not work without the former, using the same metaphor, the Court of Justice could not work without its lawyer-linguists.

43 The Annual Report on the Judicial Activity 2016 , denotes the concern in reducing the translation needs, having already reached, in 2015 and 2016 a reduction in the number of pages to be translated. See, Court of Justice of the European Union, Annual Report on the Judicial Activity 2016, p. 42; Court of Justice of the European Union, Annual Report on the Judicial Activity 2015, [available at www.curia.europa.eu, last accessed June 1, 2017], p.46. Even so, the judgment already exists six weeks prior to the translation. The judgments have to be translated into all languages and at the same time. The date of the judgment is the date of the translation and not of the decision.

${ }^{44}$ See, Ibidem, at footnote 38.
} 
of citations and clarity in drafting. ${ }^{45}$ This review takes place in two stages: i) after the drafting of the draft judgment, prepared in French by the Judge-rapporteur along with their reférendaires, and before being addressed to the members of the CJEU, the draft judgment is sent to the lecteurs d'arrêt, who carry out the first editing; ii) after the deliberation, the final judgment, drafted in French, is subjected again to a reading by the lecteurs d'arrêt. Despite being essentially stylistic, this review can have substantial repercussions and detect inconsistencies relating to the substantive content of the decision, thus interfering with the Court's legal reasoning.

Terminological consistency is an integral part of the substantive legal uniformity.

\section{ii. Formalist style and linguistic precedent}

The most evident aspect of the impact of the linguistic dimension of the decisions of the CJEU is, possibly, in the Court's legal reasoning concise, with an unchangeable structure and based on previous decisions. That legal reasoning tends to reproduce entire passages from the Court' previous decisions, sometimes copying them verbatim, without contextualisation or citation. ${ }^{46} \mathrm{~A}$ direct consequence of the multilingualism, the need for a standardised text for translation, the collegial nature (i.e., of compromise) of the judgments and of its drafting is mainly done by non-French speakers.

In fact, in multilingual legal systems in which judicial decisions are often drafted by those who are not working in their mother tongue, as is the case of a large majority of the referendaires at the CJEU, there will, inevitably, be a tendency to reproduce the exact same language used in previous judgments because such pre-established formulas, in French, have already been reviewed by the lecteurs d'arrêt, as mentioned before. In interviews with reférendaires, the author Karen McAuliffe has concluded that they feel bound, as regards the style of the documents to be drafted and to the phrases to be used. ${ }^{47}$ The reférendaires are even known for keeping glossaries with important or more frequently used concepts to expedite the drafting process. ${ }^{48}$

The frequent citations of the Court's previous decisions are almost equally binding for the lawyer-linguists who, during the translation process, should also ensure that the same, already sanctioned, expressions are used. This is not a restriction on their translation, but a form of precedent, the so-called linguistic precedent. This is so, despite the absence of any official doctrine of precedent in the EU legal system.

One effect of this repetition is the strengthening of the normative value of the jurisprudence of the CJEU. The recurrent use of the same terms and formulas led to the development of fundamental legal concepts of EU law and a consistent body of case-law, la jurisprudence constante.

\section{iii. French Style}

There are several authors who think that the choice of French as the Court's working language, which remains the same since its creation in 1952, has promoted a continuous dependence on the judicial French style, characterised as impersonal,

\footnotetext{
${ }^{45}$ See L. Neville Brown and Tom Kennedy, The Court of Justice of the European Communities, $5^{\text {th }}$ Edition (London: Sweet \& Maxwell, 2000), 24.

${ }^{46}$ See Karen McAuliffe, "Hybrid Texts and Uniform Law? The Multilingual Case Law of the Court of Justice of the European Union", in International Journal for the Semiotics of Law, vol. 24 (2011), 108.

${ }^{47}$ See Karen McAuliffe, "Hybrid Texts and Uniform Law? The Multilingual Case..., 110.

${ }^{48}$ See, Ibidem.
} 
formalist and collegiate.

For Michal Bobeck, in the 1960's and 1970's the French inspiration in the writing style of the Court was easily perceptible in the syllogistic structure, the dry tone and the abstract style of its judgments, which were also quite short. ${ }^{49}$ Giuseppe Mancini and David Keeling add that the early judgments of the Court resembled copies of the judgments of France's highest courts, namely by using the same method of exposure with the introductory formula "attendu que" used in the opening of each paragraph. ${ }^{50}$ Style that, since the 1980s, became less pronounced.

Agreeing with Anthony Arnull, "it is possible that the style of the Court's judgment is affected by the language in which they are drafted" ${ }^{51}$ However, since its creation, the Court has been exposed to different cultures and legal/judicial styles. For this reason, Jan Komárek considers that to emphasize the French influence today is an exaggeration. ${ }^{52}$

Notwithstanding, we can still find traces of this influence. The legal reasoning of the CJEU is abstract and deductive, and despite considerable developments throughout the years, the judgments remain relatively concise and generally follow an established template, as previously mentioned. In the Preliminary ruling Procedure, the final decision rendered by the Court on the adopted legal solution is often, "announced rather than discussed in great depth". ${ }^{33}$

In a clear Gallic influence, the judgments are still collegiate and dissenting or concurring Opinions are proscribed, which causes problems in a multilingual work environment. In addition, and for being a compromise text, the decisions of the CJEU may sometimes not be sufficiently clear, since they are the result of concessions, advances, and setbacks. In an effort to attain compromise, gaps in the reasoning of the Court may arise. The Judges discuss in French - which they can dominate to a greater or lesser degree - complex points of EU law to reach a consensus. The need to negotiate complex legal issues involving not infrequently fundamental rights, in a foreign language (for the majority) is one of the reasons why the judgments of the CJEU are often quite brief and formalistic, with little scope to include long explanations on the legal reasoning behind the decision.

Moreover, the deliberations at the CJEU are secret, and Judges deliberate, without interpreters or translators. Since they are not present and do not have access to the legal reasoning behind the judicial decision, or the text where they could identify those sections which corresponded to a commitment to draw up and later, translate, the référendaires and the lawyer- linguists, respectively, have to keep the language (French) of the decision ambiguous. It reinforces, as has been said, the brevity, the impersonality, and the use of pre-established formulas.

It follows that the Court has shaped its case-law around the idea of uniformity and integrity of the EU legal system as a whole, finding subterfuges to deal with the linguistic issue and the needs for translation, favouring coherence and consistency, even though, in doing so, it has, in my opinion, undermined the clarity of its speech.

\footnotetext{
${ }^{49}$ See Michal Bobeck, “The Court of Justice of the European Union”, 15.

${ }^{50}$ See Giuseppe Federico Mancini and David T. Keeling, "Language, culture and politics in the life of the European Court of Justice", 399.

${ }^{51}$ Anthony Arnull, The European Union and its Court of Justice, (Oxford: Oxford University Press, 2006), 13.

${ }^{52}$ See Jan Komárek, "Review: Questioning the Courts Deliberations", in Oxford Journal of Legal Studies 4, vol. 29 (2009), 818.

${ }^{53}$ See Michal Bobeck, “The Court of Justice of the European Union”, 15.
} 


\section{Conclusion}

In a multilingual institution such as the CJEU, Law and Language are omnipresent. The role of language and translation in the production of the case-law of the Court is significant. The linguistic dimension of the CJEU is probably the one that most influenced its jurisprudence and, by consequence, EU law.

For the production, dissemination and application of (binding) case law in 24 languages, the Court resorts to translation. However, the role of translation at the CJEU goes beyond simply converting the French version (the language in which all internal documents are drafted and the language of deliberation) into the other 23 official languages; it is embedded in the process of drafting, reasoning and decision making. This is based on multiple layers of translation, since the processing of the documents necessary for the performance of its judicial function, to the filtering of different cultures and types of legal reasoning of those involved in the process.

In the context of EU law, "the ultimate goal of legal translation is to produce parallel texts that will be interpreted and applied uniformly by the courts". ${ }^{4}$ However, it is also well documented that any type of translation, including legal translation, always involves approximation. Karen McAuliffe argues that "[t] he approximation and imprecision inherent in language and translation do have implications for the case law produced by the CJEU. The concept of a single EU legal language that allows EU law to be uniformly applied throughout the Union is, in fact, necessarily based on a legal fiction". ${ }^{55}$ This leads the same author to conclude that, although it is a feasible legal-linguistic fiction, it is still a fiction. ${ }^{56}$

In fact, the entirety of EU law (primary and secondary law and including the case law of the CJEU) functions by means of approximation. The legal concepts of Law in general and of EU law in particular, are only accessible through language. Some approximation between the different language versions of the judgments of the CJEU and other EU legal instruments simply cannot be avoided, given the indeterminate and imprecise inherent nature of the language.

The question is whether this approximation, required for multilingual jurisprudence, produces a satisfactory and unequivocal case-law. That is to say, one that is capable of producing statements of law having the same legal effect in all EU Member States, each with its own legal culture and legal traditions, in all languages in which those are published and ensure the uniform application of EU law.

It can be argued that this approximation may lead to discrepancies between language versions of the judicial decisions of the CJEU and, thus, compromise the uniform application of EU law. Nonetheless, three factors discussed earlier, multilingualism, the French origins of this Court and drafting by référendaires, result in the creation of a unique body of case law, characterised by the excessive use of pre-established phrases and references to previous decisions. Emphasis is put on consistency. These decisions are, as we have seen, binding for the lawyer-linguist whom ensures the translation. The so-called linguistic precedent is, thus, formed. This construction of the judgments from blocks of words, which is maintained by the translation, draws the attention of the multilingual legal community in relation to the autonomous nature of EU law, that the CJEU had already highlighted in its CILFIT

\footnotetext{
${ }^{54}$ Susan Šarcevic, "Legal Translation and Translation Theory: The Receiver-oriented Approach", in Genève 2000: Actes [available at www.tradulex.org last accessed June 1, 2017].

${ }^{55}$ Karen McAuliffe, "The Limitations of the Multilingual Legal System", 881.

${ }^{56}$ See, Ibidem.
} 
judgment, ${ }^{57}$ and, consequently, contributes to ensuring the uniform application of the EU law. The frequent use of EU legal terms by the CJEU in its decisions, can also help in a more uniform interpretation and application of EU law across the 28 Member States. Once the meaning of a legal term has been established by the CJEU, it becomes binding and the national courts must employ it whenever it is necessary for them to apply a legal rule of EU law in a particular case. The horizontal coherence of national legal systems is, thus, promoted.

Despite the inevitable transformation of judgments of the CJEU in translation, the notion of uniform law is not necessarily a fiction devoid of meaning. In fact, the issue of approximation in translation seems to reinforce the pluralist argument. The discursive nature of EU law and, in particular, the Preliminary ruling proceeding, may help in the uniformity of that law and, more broadly, to support the coherent and consistent evolution of the EU law and its uniform application and interpretation. But the dialogue promoted by the preliminary ruling proceeding depends on its use by national courts.

Communication does indeed appear to be a central issue on how to gradually create a uniform EU legal system. But communication requires clarity. Interpretation and reinterpretation by national courts and other legal actors, such as academics, may indeed, help in establishing uniformity, but not in the accessibility of the Court's reasoning. Indeed, the CJEU must endeavour to improve the lack of clarity and obscurity in its judicial pronouncements. In this aspect, as previously noted, the Opinions of the Advocate Generals play a key role.

Pursuant to the words uttered by Peter Dyrberg, to which I fully subscribe, "[the] uniform application is ... [a] sort of existential problem to which the [Union] legal order has to report". ${ }^{58}$

\footnotetext{
${ }^{57}$ «(...) [c]ommunity law uses terminology which is peculiar to it. Furthermore, it must be emphasized that legal concepts do not necessarily have the same meaning in Community law and in the law of the various Member States). See Judgment CILFIT, 6 October 1982, C- 283/81, EU:C:1982:335, recital 19.

${ }^{58}$ Peter Dyrberg, "What Should the Court of Justice be Doing?", in European Law Review 3, vol. 26, n. 3 (2001), 291.
} 